\title{
Efecto de la temperatura de tratamiento de un caolín en la permeabilidad a cloruros en morteros
}

\author{
Effect of kaolin treatment temperature \\ on mortar chloride permeability
}

\author{
J. Torres ${ }^{(*)}$, R. Mejía de Gutiérrez ${ }^{(*)}$ y F. Puertas ${ }^{(* *)}$
}

Recepción/Received: 16-II-06

Aceptación/Accepted: 1-VI-06

\section{RESUMEN}

En el presente trabajo se incluyen los resultados de la resistencia a la penetración de cloruros de morteros de Cemento Portland Ordinario (OPC) adicionados con un caolín colombiano sometido a tratamiento térmico en un rango de temperaturas entre 600 y $800^{\circ} \mathrm{C}$. Los productos del tratamiento térmico, metacaolín (MK), son incorporados en mezclas de morteros de OPC en proporciones del 10 y $20 \%$ en relación al peso del cemento. Se comparan sus características físico-químicas, entre las cuales se incluye la microestructura de poros evaluada por la técnica de porosimetría de mercurio, con la absorción capilar y la permeabilidad a cloruros. Se concluye que las muestras adicionadas con un $20 \%$ del material tratado térmicamente a $800{ }^{\circ} \mathrm{C}$ presentan el mejor desempeño en sus propiedades finales.

Palabras clave: metacaolín, morteros, durabilidad, absorción capilar, permeabilidad.

\section{SUMMARY}

The present paper discusses the results of chloride resistance tests conducted on ordinary Portland cement (OPC) mortars containing a Colombian kaolin pre-treated at temperatures of from 600 to $800{ }^{\circ} \mathrm{C}$. The resulting metakaolin (MK) was added to OPC mortar mixes in proportions of 10 and $20 \%$ by cement weight. The mortars were compared for physical and chemical properties, including capillary absorption, chloride permeability and pore microstructure as assessed by mercury porosimetry. The best performance was recorded for the samples containing $20 \%$ of the material treated at $800^{\circ} \mathrm{C}$.

Keywords: metakaolin, mortars, durability, capillary absorption, chloride permeability.

\section{INTRODUCCIÓN}

Un hormigón durable debe mantener su forma original, calidad y buena prestación cuando se expone al ambiente de servicio. Sin embargo, en algunos casos, la acción del medio o la calidad del hormigón contribuyen a fenómenos

\section{INTRODUCTION}

Durable concrete should maintain its original shape, quality and performance when exposed to service conditions. Yet in some cases, environmental action or concrete quality may contribute to deterioration,

\footnotetext{
(*) Universidad del Valle, Calí, Colombia.

(**) Instituto de Ciencias de la Construcción Eduardo Torroja (CSIC), Madrid (España).
} 
de deterioro que conducen a una rápida intervención, ya sea de rehabilitación o reemplazo de la estructura (1). Entre las formas de ataque se pueden citar: la reacción álcali-sílice, la carbonatación, los ciclos de hielo-deshielo, el ataque de cloruros y el de sulfatos, entre otras. Muchas de estas acciones, físicas o químicas, conducen finalmente a la corrosión del acero de refuerzo.

Una de las formas de proporcionarle una mayor durabilidad al hormigón, e indirectamente al acero, se logra disminuyendo su permeabilidad, de tal manera que se reduce el ingreso de agua y de agentes agresivos. Para ello, una alternativa es la incorporación de adiciones o materiales suplementarios en la mezcla, tales como las puzolanas o escorias siderúrgicas de alto horno, las cuales, a su vez, pueden contribuir en el mejoramiento de otras propiedades (2). Estas adiciones activas inducen cambios microestructurales en las pastas y hormigones, debido a la mayor formación de gel CSH y al refinamiento de la estructura porosa con una mayor proporción de meso y microporos en estos materiales respecto a los correspondientes sin adición (3).

Dentro de las adiciones puzolánicas se encuentra el metacaolín (MK), que se produce por medio de un tratamiento térmico controlado de una arcilla caolinítica (filosilicato de fórmula $\mathrm{Al}_{2} \mathrm{O}_{3} \cdot \mathrm{SiO}_{2} \cdot 2 \mathrm{H}_{2} \mathrm{O}$ ). Este material ha sido considerado como una puzolana de alta reactividad ya que reacciona con el $\mathrm{Ca}(\mathrm{OH})_{2}$ generado en la hidratación de los silicatos, contribuyendo al mejoramiento de propiedades tanto mecánicas como de durabilidad de los morteros y hormigones (4-8). El efecto de las propiedades mineralógicas del caolín, los parámetros del tratamiento térmico, el grado de deshidroxilación, entre otros factores, en la actividad puzolánica del metacaolín, ha sido objeto de diferentes investigaciones (9-12); sin embargo, no se reportan estudios acerca de la influencia de la temperatura de tratamiento del caolín en el desempeño durable de las mezclas cementicias adicionadas.

El presente trabajo de investigación analiza la relación entre la temperatura de tratamiento térmico del caolín y algunas propiedades de durabilidad de morteros adicionados, particularmente el efecto en la permeabilidad y la resistencia a iones agresivos como los cloruros.

\section{MATERIALES Y PROCEDIMIENTO EXPERIMENTAL}

Para la realización de la investigación se seleccionó un caolín colombiano disponible comercialmente. En la Tabla 1 se presenta su composición química. Este caolín fue tratado térmicamente, durante 2 horas, a temperaturas de 600 , 700 y $800{ }^{\circ} \mathrm{C}$. Estas condiciones de tratamiento fueron optimizadas en estudios anteriores (13), en los que se necessitating speedy repair in the form of structural rehabilitation or replacement (1).Some of the more prominent forms of attack include alkali-silicate reaction, carbonation, freeze-thaw cycles and chloride and sulphate attack. Many of these physical or chemical actions ultimately corrode reinforcing steel.

One of the ways to enhance concrete -and indirectly steel-durability is by lowering its permeability to reduce water and aggressive agent ingress. This can be achieved, among others, by adding supplementary materials such as pozzolans or blast furnace slag to the mix, which may improve other properties as well (2). These active additions induce microstructural changes in pastes and concretes due to the formation of larger amounts of $\mathrm{CSH}$ gel and the refinement of the pore structure: as a result, these materials exhibit a higher proportion of meso- and micropores than the unadditioned equivalents (3).

Metakaolin (MK), one such pozzolanic addition, is produced by controlled thermal treatment of a kaolinitic clay (a filosilicate whose formula is $\mathrm{Al}_{2} \mathrm{O}_{3} \cdot \mathrm{SiO}_{2} \cdot 2 \mathrm{H}_{2} \mathrm{O}$ ). This material is regarded to be a highly reactive pozzolan because its reaction with the $\mathrm{Ca}(\mathrm{OH})_{2}$ generated during silicate hydration contributes to improvements in mortar and concrete mechanical strength and durability (4-8). The effect of the mineralogical properties of the kaolin used, the thermal treatment parameters and the degree of dehydroxylation on the pozzolanic activity of metakaloin has been the subject of a number of studies (9-12). There are no reports in the literature, however, on how kaolin treatment temperature may affect the durability of additioned cementitious mixes.

In the present study an analysis was conducted of the relationship between kaolin treatment temperature and certain properties that determine additioned mortar durability, particularly permeability and resistance to aggressive ions such as chlorides.

\section{MATERIALS AND EXPERIMENTAL}

The chemical composition of the commercial Colombian kaolin chosen for the study is given in Table 1. This kaolin was thermally treated for two hours at 600,700 and $800{ }^{\circ} \mathrm{C}$, temperatures optimized in preceding studies (13) for the production of the most pozzolanically active metakaolin. The metakaolin samples 
demostró que este rango de temperaturas induce las mayores propiedades puzolánicas en el metacaolín. La caracterización de los diferentes metacaolines obtenidos fue realizada por difracción de rayos $x$ (DRX), utilizando un equipo RX-Rigaku RINT 2200 y Resonancia Magnética Nuclear (27Al RMN) en un equipo Bruker MSL 400.

Probetas de mortero cúbicas de $50 \mathrm{~mm}$ se elaboraron con Cemento Portland Ordinario (OPC) cuya composición química se presenta en la Tabla 1; y arena de Ottawa en una proporción de cemento:arena de 1:2,75. Los productos obtenidos después del tratamiento térmico del caolín a temperaturas de 600,700 y $800{ }^{\circ} \mathrm{C}$ fueron adicionados a los morteros de OPC en proporciones del 10 y $20 \%$ con respecto a la cantidad de cemento. Se utilizó una relación agua/cementante $(\mathrm{a} / \mathrm{C})$ constante de 0,5 , para lo cual fue necesaria la incorporación de un aditivo superplastificante, Sikament NS, que fue incorporado en dosis del $1 \%$ en el mortero patrón y hasta del $2,5 \%$ en las mezclas de MK al $20 \%$. El curado de los morteros se realizó por un periodo de 60 días a temperatura ambiente bajo agua saturada con $\mathrm{Ca}(\mathrm{OH})_{2}$.

Se evaluó el comportamiento frente a la permeabilidad mediante la técnica de succión capilar con base en los métodos de Fagerlund (14) y EMPA (15). La resistencia a la penetración de cloruros se determinó con base en la norma ASTM C1202. Adicionalmente se aplicó la técnica de porosimetría de intrusión de mercurio, para determinar el tamaño promedio y la distribución de poros utilizando para ello el equipo Micromeritics 9320 Pore Sizer V2.02.

\section{RESULTADOS Y DISCUSIÓN}

\subsection{Características del metacaolín por efecto del tratamiento térmico}

En la Figura 1 se muestran los difractogramas del caolín original y los correspondientes materiales obtenidos en el rango de 600 a $800{ }^{\circ} \mathrm{C}$. Dichos difractogramas muestran

Tabla 1 / Table 1

Composición química de materiales de partida Chemical composition of raw materials

\begin{tabular}{|lll|}
\hline Componente / Component, \% & Caolín / Kaolin & OPC \\
\hline $\mathrm{SiO}_{2}$ & 45.46 & 19.83 \\
\hline $\mathrm{Al}_{2} \mathrm{O}_{3}$ & 38.87 & 6.35 \\
\hline $\mathrm{Fe}_{2} \mathrm{O}_{3}$ & 1.30 & 4.18 \\
\hline $\mathrm{CaO}$ & - & 63.33 \\
\hline $\mathrm{MgO}$ & - & 2.54 \\
\hline $\mathrm{SO}_{3}$ & - & 2.20 \\
\hline $\mathrm{L} . \mathrm{O} . \mathrm{I}$ & 14.05 & 0 \\
\hline
\end{tabular}

obtained were characterized by $X$-ray diffraction (XRD) with an RX-Rigaku RINT 2200 diffractometer and nuclear magnetic resonance $\left({ }^{27} A l\right.$ NMR) on a Bruker MSL 400 apparatus.

Fifty-mm cubic mortar specimens were made with Ordinary Portland Cement (OPC), whose composition is also given in Table 1, and Ottawa sand with a cement:sand ratio of 1:2.75. The products obtained from thermal treatment of the kaolin at temperatures of 600, 700 and $800{ }^{\circ} \mathrm{C}$ were added to OPC mortars at $10 \%$ and $20 \%$ by cement weight. A water:cement (w:c) ratio of 0.5 was used throughout, necessitating the inclusion of a superplasticizer, Sikament NS. The admixture dose ranged from $1 \%$ in the control mortar up to $2.5 \%$ in the mixes containing 20\% MK. The mortars were cured for 60 days at laboratory temperature submerged in $\mathrm{Ca}(\mathrm{OH})_{2}$-saturated water.

Permeability behaviour was assessed with capillary suction techniques based on the Fagerlund (14) and EMPA (15) methods. Chloride penetration resistance was determined on the basis of ASTM standard C1202. Mercury intrusion porosimetry techniques were used, in turn, to determine mean pore size and pore distribution with a Micromeritics 9320 V2.02 Pore Sizer.

\section{RESULTS AND DISCUSSION}

\subsection{Metakaolin characteristics after thermal treatment}

Figure 1 shows the XRD traces for the original kaolin and the materials obtained in the 600 to $800^{\circ} \mathrm{C}$ range.

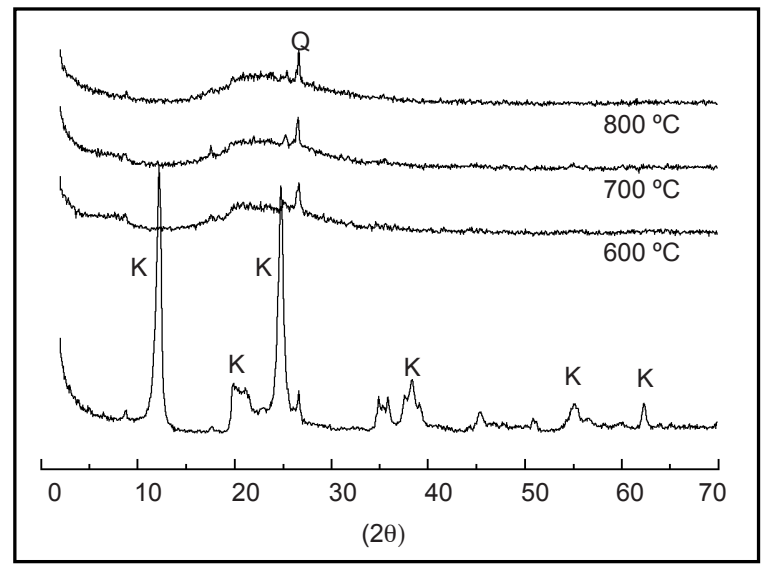

Figura 1. Espectro de difracción de rayos $\mathrm{X}$. Figure 1. XRD patterns. 


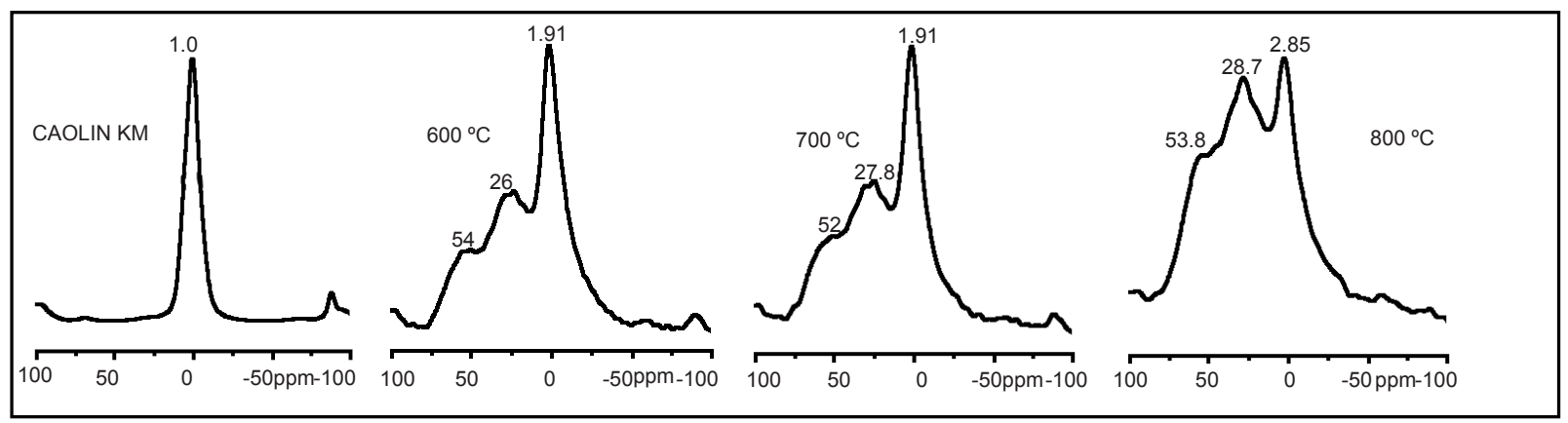

Figura 2. Espectro 27AI MAS-NMR.

Figure 2. ${ }^{27}$ Al MAS-NMR spectra.

que en todos los casos el metacaolín obtenido presenta características amorfas. La única línea de difracción identificada en $d=3,34 \AA\left(2 \theta=26,6^{\circ}\right)$ corresponde al cuarzo presente en el caolín de partida.

El espectro $27 \mathrm{Al}$ MAS-NMR del caolín registrado a 104,2 $\mathrm{MHz}$ presenta un pico ubicado en 1,0 ppm, característico de la coordinación octaédrica del aluminio $\left(\mathrm{Al}_{\mathrm{O}}\right)$; cuando el mineral es tratado a temperatura superior a $600{ }^{\circ} \mathrm{C}$ aparecen dos nuevos picos ubicados alrededor de 54 y 26 ppm, que se atribuyen a la coordinación $4\left(\mathrm{Al}_{\mathrm{T}}\right)$ y $5\left(A l_{P}\right)$, respectivamente, simultáneamente la intensidad del pico en 1 ppm se ve disminuida, tal como se puede apreciar en la Figura 2. El espectro de la muestra obtenida a $800{ }^{\circ} \mathrm{C}$ presenta una mayor proporción de $\mathrm{Al}_{\mathrm{T}}$ y $\mathrm{Al}_{\mathrm{p}}$ que las otras dos muestras tratadas térmicamente, lo que está indicando un mayor desorden estructural y, por tanto, una mayor amorficidad, siendo estos resultados coincidentes con la más elevada reactividad puzolánica de este material (13).

\subsection{Durabilidad de morteros con metacaolín}

En las Figuras 3 y 4 se presentan los resultados del ensayo de succión capilar, donde se pueden apreciar la resistencia a la penetración de agua $m\left(x 10^{7} \mathrm{~s} / \mathrm{m}^{2}\right)$ y el coeficiente de absorción capilar $K\left(\times 10^{-2}\right)$ $\left(\mathrm{kg} / \mathrm{m}^{2} . \mathrm{s}^{1 / 2}\right)$, respectivamente. En términos generales todos los morteros adicionados con MK presentaron un mejor comportamiento en comparación con la muestra control, lo cual indica una reducción en la permeabilidad de los mismos. Este efecto se hace más notorio al incrementar el contenido de la puzolana. Estos resultados están de acuerdo con lo expresado por J. Khatib y R. Clay (16).

En cuanto al efecto de la temperatura de tratamiento del caolín, se observa que la muestra adicionada con caolín tratado a $800{ }^{\circ} \mathrm{C}$ presentó un comportamiento superior, pues el coeficiente de absorción capilar se redujo hasta un $60,5 \%$ y la resistencia a la penetración de agua se
According to these patterns, the metakaolin obtained was completely amorphous, with the exception of a diffraction peak identified at $d=3.34 \AA\left(2 \theta=26.6^{\circ}\right)$, corresponding to the quartz present in the initial kaolin.

The 27Al MAS-NMR spectrum for kaolin recorded at 104.2 MHz exhibited a peak at $1.0 \mathrm{ppm}$, characteristic of octahedral coordination of the aluminium $\left(A L_{0}\right)$. When the mineral was treated at a temperature over $600{ }^{\circ} \mathrm{C}$, two new peaks appeared, at around 54 and 26 ppm, respectively attributed to tetra- $\left(A I_{T}\right)$ and penta$\left(A l_{P}\right)$ coordination. The intensity of the peak at $1 \mathrm{ppm}$ declined on this spectrum, as Figure 2 shows. The higher proportions of $A I_{T}$ and $A l_{P}$ observed on the spectrum for the sample obtained at $800^{\circ} \mathrm{C}$ than the other two thermally treated samples are indicative of greater structural disorder and therefore greater amorphism; such findings are consistent with the higher pozzolanic activity observed for this material (13).

\subsection{Durability of mortars containing metakaolin}

Figures 3 and 4 show the results of the capillary suction test in terms of water penetration resistance $m\left(x 10^{7} \mathrm{~s} / \mathrm{m}^{2}\right)$ and the capillary absorption coefficient $K$ (x10-2) $\left(\mathrm{Kg} / \mathrm{m}^{2} . \mathrm{s}^{1 / 2}\right)$, respectively. Generally speaking, all the mortars containing MK performed better -i.e., exhibited lower permeability - than the control. This effect was more visible at higher pozzolan content. These findings concur with data reported by J. Khatib and R. Clay (16).

The sample containing kaolin thermally treated at $800{ }^{\circ} \mathrm{C}$ performed best, with a $60.5 \%$ decline in the capillary absorption coefficient and a $200 \%$ increase in water penetration resistance compared to the control. These findings are consistent with the higher 


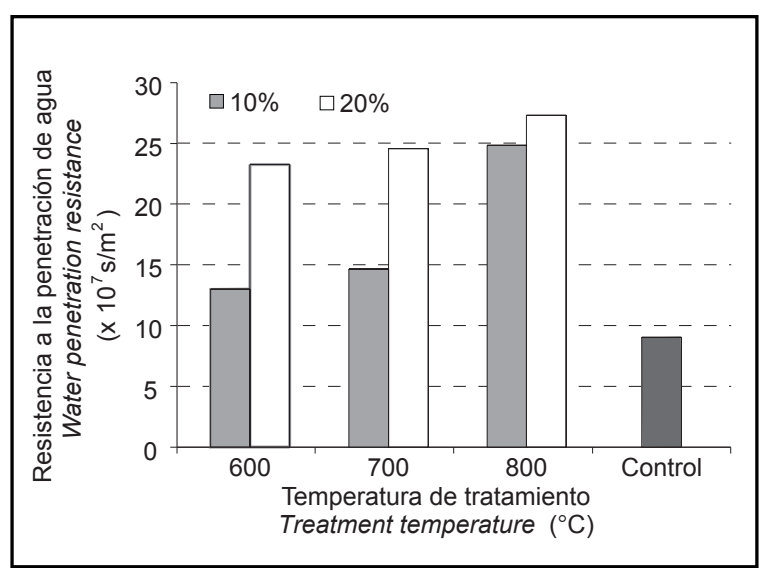

Figura 3. Resistencia a la Penetración de agua. Figure 3. Water penetration resistance.

incremento en el $200 \%$ con respecto a la muestra patrón. Este desempeño coincide con la mayor actividad puzolánica del metacaolín obtenido a esta temperatura, comparado a las muestras tratadas a 600 y $700{ }^{\circ} \mathrm{C}(13)$.

El excelente comportamiento frente a la permeabilidad capilar de los morteros adicionados se atribuye al refinamiento de la estructura de los poros de la matriz como consecuencia de la reacción puzolánica del MK y el hidróxido de calcio producido en la reacción de hidratación del cemento, que provocan un efecto de micro relleno y por lo tanto alteran la estructura porosa (4). Lo anterior se pudo comprobar por medio de la aplicación de la técnica de Porosimetría de Intrusión de Mercurio, tal como se aprecia, para los morteros con el $20 \%$ de adición, en los resultados presentados en la Tabla 2 y en la Figura 5. El diámetro promedio de poro se reduce en un porcentaje alrededor del $80 \%$ para las muestras tratadas a las diferentes temperaturas en comparación con la muestra control. En cuanto a la distribución de los poros, se observa para los morteros patrón una distribución mayoritaria en el rango entre 0,01 y $1 \mu \mathrm{m}(90 \%)$, donde el $50 \%$ de los poros presenta un tamaño superior a $0,1 \mu \mathrm{m}$; por el contrario en los morteros adicionados con MK, independientemente de la temperatura de obtención, el mayor porcentaje de poros (aproximadamente un $80 \%$ ) se ubica en el rango de 0,01 a 0,1 $\mu \mathrm{m}$.

Aunque la porosidad total, evaluada por Porosimetría de Mercurio (Tabla 2), fue en algunos casos superior para los morteros adicionados, estos resultados indican que los morteros conteniendo MK presentan menor diámetro de poros y diferente distribución de la red porosa comparados al mortero de control. Estos cambios microestructurales determinan la baja permeabilidad. En este sentido, otros estudios realizados con MK de diferente procedencia han reportado resultados similares $(4,8,17-19)$.

La evaluación del comportamiento frente a los iones cloruro, se realizó aplicando el ensayo de permeabilidad

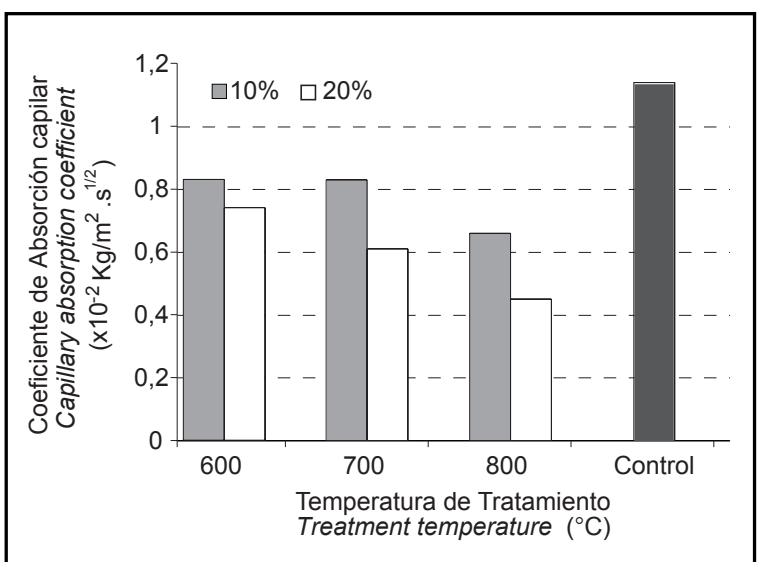

Figura 4. Ensayo de Absorción capilar. Figure 4. Capillary absorption test.

pozzolanic activity of metakaolin at that temperature than at 600 to $700{ }^{\circ} \mathrm{C}(13)$.

The low capillary permeability of the additioned mortars was attributed to the refinement of the matrix pore structure as a result of the pozzolanic reaction between the $M K$ and the calcium hydroxide produced during cement hydration, which generated a micro-fill effect, altering the pore structure (4). Mercury Intrusion Porosimetry trials confirmed such refinement and alteration for mortars with $20 \%$ additions. As the results in Table 2 and Figure 5 show, the mean pore diameter was $80 \%$ lower in the samples treated at different temperatures than in the control. Pore distribution in the latter, in turn, fell within the 0.01 to 1 um range (90\%), with $50 \%$ of the pores larger than $1 \mu \mathrm{m}$, whereas in mortars containing $M K$, regardless of the temperature of thermal treatment, the highest percentage of pores (approximately $80 \%$ ) was in the 0.01 to $0.1 \mu \mathrm{m}$ range.

Although total porosity as assessed by mercury porosimetry (Table 2) was higher in some cases for the additioned mortars, these results also showed a smaller pore diameter and different pore network distribution in the MK-containing than in the control mortar. The above microstructural changes determined low permeability. Similar results have been reported by other authors (4, 8, 17-19) working with MK.

Chloride ion penetration was assessed with the rapid chloride permeability test as described in ASTM standard 
rápida a cloruros según la norma ASTM C1202. Los resultados del índice de carga, calculado en relación a la carga determinada para el mortero patrón se presenta en la Tabla 3. Se observa que, en general, todos los morteros adicionados con MK presentaron un mejor desempeño en comparación con la muestra patrón (OPC), coincidiendo así con los resultados obtenidos en el ensayo de porosidad. Entre las muestras se destaca la adicionada con caolín tratado a $800{ }^{\circ} \mathrm{C}$, debido a que la reducción en la penetración de cloruros con respecto a OPC fue de un $65 \%$ para las muestras adicionadas al $10 \%$; y de un $88 \%$ para la proporción de adición del $20 \%$. Cabe anotar que a una proporción del $20 \%$, no es apreciable el efecto de la temperatura de obtención del MK en esta propiedad.

El Coeficiente de Difusión de cloruros para el mortero de control y el correspondiente con $20 \%$ de $\mathrm{MK}$, obtenido a temperatura de $800{ }^{\circ} \mathrm{C}$, curado durante 60 días, se determinó aplicando un ensayo de difusión modificado (20), utilizando probetas de $10 \mathrm{~mm}$ de espesor. Estas probetas fueron colocadas en una celda de difusión que contenía solución de $\mathrm{Ca}(\mathrm{OH})_{2}$ y $\mathrm{NaCl}$ al 3,5\%. Se aplicó un voltaje de $12 \mathrm{~V}$ y se hicieron mediciones de la cantidad de cloruros que difunde a través de la muestra con respecto al tiempo. El análisis de los resultados indicó los siguientes coeficientes:

Muestra de control (OPC): $1,42 \times 10^{-12} \mathrm{~m}^{2} / \mathrm{s}$

MK $\left(800^{\circ} \mathrm{C}\right)-20 \%: 0,36 \times 10^{-12} \mathrm{~m}^{2} / \mathrm{s}$

Según estos resultados, el coeficiente de difusión en la muestra adicionada es un $75 \%$ inferior con respecto a la muestra de control. Este desempeño frente a la difusión de cloruros concuerda con lo expresado por otros investigadores $(6,21)$. A partir de los resultados encontrados, se puede afirmar que la adición de MK en morteros reduce la permeabilidad a los iones cloruro en los morteros. Este comportamiento, aunque en parte es atribuible a la modificación de la microestructura como consecuencia de la adición puzolánica expresada anteriormente, puede también atribuirse al elevado contenido de alúmina en el MK, componente capaz de enlazar los iones cloruro para producir la sal de Friedel (7).

Tabla 2 / Table 2

Diámetro promedio de poros

Average Pore Diameter for cement mortars

\begin{tabular}{|lcc|}
\hline Muestra & \multicolumn{3}{c|}{$\begin{array}{c}\text { Diametro promedio de poros Porosidad total (\%) } \\
\text { Sample }\end{array}$} & Mean pore diameter $(\mathrm{mM})$ & Total porosity (\%) \\
\hline $\mathrm{OPC}$ & 0.1286 & 15.63 \\
\hline $20 \% \mathrm{MK}\left(600^{\circ} \mathrm{C}\right)$ & 0.0253 & 16.37 \\
\hline $20 \% \mathrm{MK}\left(700^{\circ} \mathrm{C}\right)$ & 0.0272 & 14.41 \\
\hline $20 \% \mathrm{MK}\left(800^{\circ} \mathrm{C}\right)$ & 0.0275 & 15.39 \\
\hline
\end{tabular}

C1202. The charge passed, expressed in terms of the values found for the control mortar, are given in Table 3. All the MK-additioned mortars were observed to perform better than the (OPC) control, a finding that concurs with the porosity test results. The sample containing kaolin and treated at $800{ }^{\circ} \mathrm{C}$, in particular, showed $65 \%$ lower chloride penetration in the matrices with $10 \%$ additions, and $88 \%$ lower in the materials with a $20 \%$ MK content. Moreover, the effect of the temperature for obtaining MK on this property was negligible in the $20 \%$ samples.

The 60-day chloride Diffusion Coefficient for the control and the 20\%, $800{ }^{\circ} \mathrm{C}$ MK mortars was found with a modified diffusion test (19) conducted on 10-mm thick specimens. The prisms were placed in a diffusion cell containing a $3.5 \% \mathrm{Ca}(\mathrm{OH})_{2}$ and $\mathrm{NaCl}$ solution. A $12-\mathrm{V}$ current was applied and the amount of chlorides passing through the sample was measured over time. An analysis of the results yielded the following coefficients:

$$
\begin{aligned}
& \text { Control (OPC) sample: } 1.42 \times 10^{-12} \mathrm{~m}^{2} / \mathrm{s} \\
& M K\left(800^{\circ} \mathrm{C}\right)-20 \%: 0.36 \times 10^{-12} \mathrm{~m}^{2} / \mathrm{s}
\end{aligned}
$$

According to these results, the diffusion coefficient in the additioned sample was $75 \%$ lower than in the control. This chloride penetration resistance value concurred with reports by other authors $(6,21)$. Based on the results obtained, adding MK to mortar may be said to lower its chloride ion permeability. Although partially attributable to the modification of the microstructure resulting from the pozzolanic addition discussed earlier, this effect may also be due to the high alumina content in $M K$, inasmuch as this component can bond to the chloride ions to produce Friedel's salt (7).

Tabla 3 / Table 3

Permeabilidad a Cloruros (ASTM C1202)

Permeability to Chloride Ions (ASTM C1202)

\begin{tabular}{|ccc|}
\hline $\begin{array}{c}\text { Temperatura de tratamiento } \\
\text { Temperature of treatment }\end{array}$ & $\begin{array}{c}\text { MK\% } \\
\text { Téndice de carga (culombios) } \\
\text { Charge index (coulombs) }\end{array}$ \\
\hline- & 0 & 1,000 \\
\hline \multirow{2}{*}{$600^{\circ} \mathrm{C}$} & 10 & 0,434 \\
& 20 & 0,128 \\
\hline \multirow{2}{*}{$700^{\circ} \mathrm{C}$} & 10 & 0,435 \\
& 20 & 0,124 \\
\hline \multirow{2}{*}{$800^{\circ} \mathrm{C}$} & 10 & 0,348 \\
& 20 & 0,119 \\
\hline
\end{tabular}


Para comprobar la formación de la sal de Friedel, se prepararon pastas de la muestra patrón de cemento adicionado al $20 \%$ con caolín tratado térmicamente a $700^{\circ} \mathrm{C}$ y otra pasta con cal y material tratado térmicamente a la misma temperatura anterior y una relación de 1:1 (Cal:MK). Para la elaboración de las pastas se utilizó una solución de $\mathrm{NaCl}$ al $1 \%$ de concentración. Las muestras se sometieron a un curado de 60 días a una temperatura de $40^{\circ} \mathrm{C}$. Una vez cumplido este tiempo, se procedió a la aplicación de la técnica de difracción de rayos $X$ para identificar la presencia de la sal de Friedel en las diferentes mezclas. En la Figura 6 se presenta el difractograma correspondiente.

En difracción de rayos $\mathrm{X}$, la sal de Friedel $\left(\mathrm{C}_{4} \mathrm{Al}_{2} \mathrm{O}_{4} \mathrm{Cl}_{2}\right.$. $\left.10 \mathrm{H}_{2} \mathrm{O}\right)$ presenta el pico más intenso en $\mathrm{d}=7,9 \AA(2 \theta=$ $11,18)$. Efectivamente, este compuesto aparece en cada una de las pastas evaluadas (Figura 6); sin embargo, se observan intensidades más altas para las mezclas con MK que para la muestra control. Es importante tener en cuenta que para la pasta de cemento-MK al $20 \%$ el cemento se encuentra diluido, es decir, contiene un $20 \%$ menos de cemento en comparación con la pasta control. Observando la gráfica, para la muestra con el $20 \%$ de MK, el pico de la sal de Friedel se mantiene, incluso con una intensidad un poco superior, lo que quiere decir que dicha sal no sólo se forma a partir de los aluminatos cálcicos presentes en el cemento, sino también es debido a una contribución del MK; lo cual pudo reafirmarse en las mezclas de MK y cal. Esto corrobora el aporte de la alúmina presente en la adición en el excelente comportamiento del MK frente a la permeabilidad de los cloruros, coincidiendo con resultados obtenidos en estudios anteriores con MK de diferente procedencia (7).

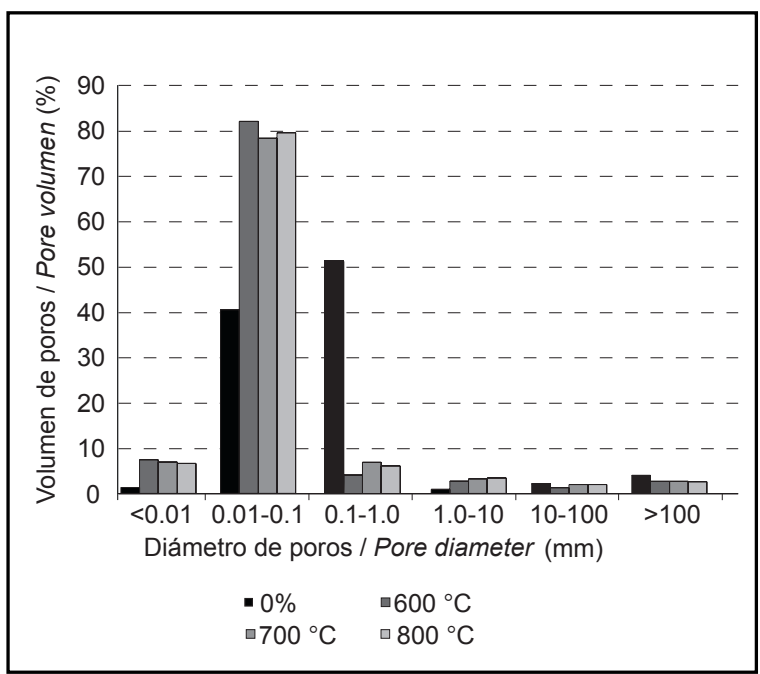

Figura 5. Distribución de poros.

Figure 5. Sample Pores Distribution.
The formation of Friedel's salt was verified in the control paste as well as in cement containing $20 \%$ thermally treated $\left(700{ }^{\circ} \mathrm{C}\right)$ kaolin and a third paste made with lime and $\mathrm{MK}\left(700^{\circ} \mathrm{C}\right)$ at a ratio of $1: 1 . \mathrm{A} 1 \% \mathrm{NaCl}$ solution was used to prepare the pastes. The samples were cured for 60 days at $40^{\circ} \mathrm{C}$ and thereafter examined with $X$-ray diffraction techniques to identify the presence of Friedel's salt in the various mixes. The resulting diffractogram is shown in Figure 6.

Under X-ray diffraction, Friedel's salt $\left(\mathrm{C}_{4} \mathrm{Al}_{2} \mathrm{O}_{4} \mathrm{Cl}_{2}\right.$. $10 \mathrm{H}_{2} \mathrm{O}$ ) generated the most intense peak at $d=7.9 \AA$ ( $2 \theta$ $=11.18)$. This compound did, in fact, appear in all the pastes studied (see Figure 6); the intensity was higher for the mixes containing $M K$, however, than for the control. Account must taken of the fact that for the cement with $20 \% \mathrm{MK}$, the cement is diluted, i.e., there is $20 \%$ less cement than in the control. As the graph shows, in the 20\% MK sample the Friedel's salt peak did not decline and was in fact even slightly more intense than in the control. The inference is that the salt was formed not only from the calcium aluminates in the cement, but also partly due to the presence of the $M K$, a finding confirmed by the results for the MK-lime mix. This corroborated the contribution of the alumina content in the addition to excellent $M K$ chloride permeability performance and is consistent with the results obtained in preceding studies with MK of varying origin (7).

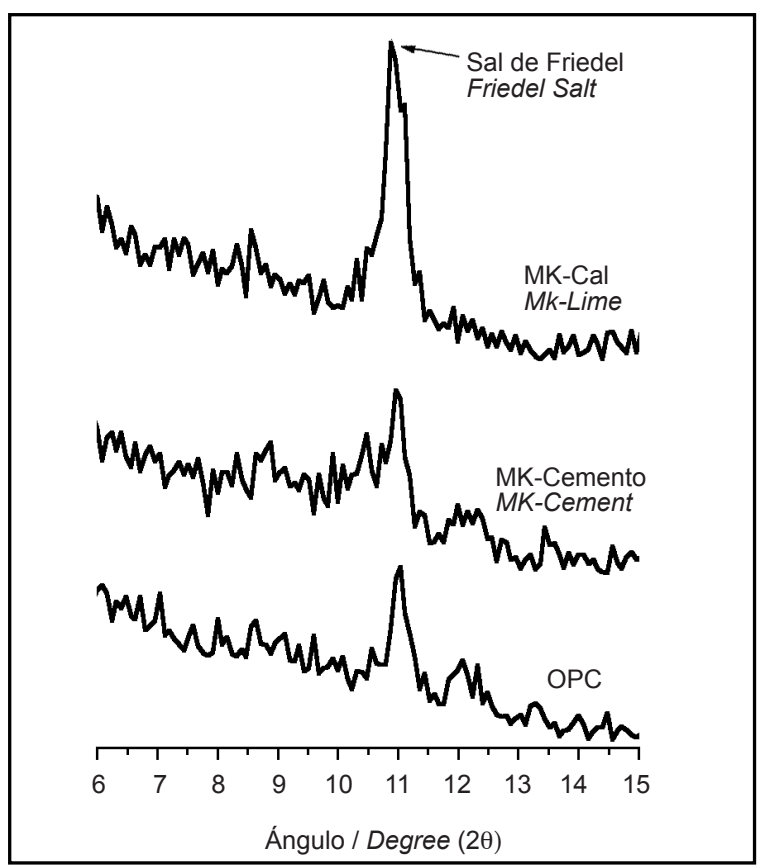

Figura 6. Difractograma de rayos $X$ - Sal de Friedel. Figure 6. X Rays Patterns - Friedel Salt. 


\section{CONCLUSIONES}

El estudio de caracterización realizado por ${ }^{27} \mathrm{Al}$ RMN sobre los metacaolines obtenidos a $600^{\circ}, 700^{\circ}$ y $800{ }^{\circ} \mathrm{C}$ demuestra un mayor desorden estructural $y$, por tanto, un mayor carácter amorfo y reactividad en la muestra tratada a $800{ }^{\circ} \mathrm{C}$.

Los estudios de durabilidad han demostrado que los morteros adicionados con metacaolín obtenido a $800^{\circ} \mathrm{C}$, y de estos aquéllos con mayor porcentaje en la mezcla ( $20 \%$ con respecto a la cantidad de cemento) presentan la menor porosidad capilar y la menor permeabilidad a cloruros. Esto, como cabía esperar, es atribuible a una modificación en la distribución de la red de poros.

Cabe anotar que el material tratado a 600 y $700{ }^{\circ} \mathrm{C}$ e incorporado en proporción del $20 \%$ da lugar a resultados aceptables y muy superiores a los reportados por el mortero sin adición, por lo cual podría pensarse en la elaboración del MK a menores temperaturas para incurrir en menor gasto energético. El efecto de la temperatura de obtención del MK se aprecia en mayor grado en las mezclas con bajo contenido de MK (10\%).

Se ha demostrado que la alúmina presente en el metacaolín participa en la formación de sal de Friedel y, por tanto, contribuye a la menor permeabilidad de cloruros.

\section{AGRADECIMIENTOS}

Los autores agradecen al Departamento de Síntesis, Caracterización y Estabilidad de Materiales del Instituto de Ciencias de la Construcción Eduardo Torroja IETcC (CSIC España), la Universidad del Valle (Colombia), Colciencias y al Centro de Excelencia en Nuevos Materiales CENM por el apoyo en la realización del presente trabajo.

\section{CONCLUSIONS}

According to the ${ }^{27} \mathrm{Al}$ NMR characterization study, of the metakaolins obtained at 600, 700 and $800{ }^{\circ} \mathrm{C}$, the sample treated at $800{ }^{\circ} \mathrm{C}$ showed greatest structural disorder and therefore amorphism and reactivity.

Durability studies proved that mortars additioned with metakaolin obtained at $800{ }^{\circ} \mathrm{C}$, and of these, the ones with a higher percentage of the compound in the mix (20\% in terms of cement), exhibited the lowest capillary porosity and highest chloride penetration resistance. That, unsurprisingly, was attributable to a change in pore network distribution.

Inasmuch as material treated at 600 and $700{ }^{\circ} \mathrm{C}$ and containing $20 \%$ kaolin yielded acceptable and much better results than in the unadditioned control, the possibility of generating $M K$ at lower temperatures might be considered for the energy savings involved. The effect of the temperature used to produce MK was more visible in the mixes with low MK contents (10\%).

The alumina present in the metakaolin was shown to participate in the formation of Friedel's salt and consequently to contribute to lower chloride permeability.

\section{ACKNOWLEDGEMENTS}

Thanks for their support in the present study go to the Eduardo Torroja Institute for Construction Science's (IETCC) Department of Materials Synthesis, Characterization and Stability (CSIC - Spain), the Valle University (Colombia) and the New Materials Centre for Excellence (CENM).

\section{BIBLIOGRAFÍA / BIBLIOGRAPHY}

(1) Keck, R.: "Improving concrete durability with cementitious materials", Concrete International, vol. 23, 9 (2001), pp. 47-51.

(2) Mehta, P. K.: "Pozzolanic and Cementituous by-product", $3^{\text {rd }}$ Int. Conf. on Fly Ash, Silica Fume, Slag and Natural Puzzolans in Concrete (Trondheim), SP 114-1, 1-43 (1989).

(3) Menéndez, G; Bonavetti, V. L.; Irassar, E. F.: "Ternary blended cement concrete. Part I: Early age properties and mechanical strength", Mater. Construcc., vol. 56, 284 (2006), pp. 55-67.

(4) Khatib, J. M. y Wild, S.: "Pore Size Distribution of Metakaolin Paste", Cement and Concrete Research, vol. 26, 10 (1996), pp. $1545-1553$.

(5) Boddy, R.; Hooton, D. y Gruber, K. A.: "Long-Term Testing of the Chloride-penetration Resistance of Concrete Containing High-Reactivity Metakaolin", Cement and Concrete Research, vol. 31 (2001), pp. 759-765.

(6) Gruber, K. A.: "Increasing Concrete Durability with High-Reactivity Metakaolin", Cement and Concrete Composites, vol. 23 (2001), pp. 479-484.

(7) Gutiérrez, R. M. de; Delvasto, S. y Talero, R.: "Una nueva puzolana para materiales cementicios de elevadas prestaciones", Materiales de Construcción, vol. 50, 260 (2000), pp. 5-12.

(8) Frías, M. y Sánchez de Rojas, M. I.: "Influencia del metacaolín en la estructura porosa de matrices a base de MC/Cemento", Mater. Construcc., vol. 50, 259 (2000), pp. 57-67. 
(9) Shvarzman, A. et al: "The effect of dehydroxilation/amorphization degree on pozzolanic activity of kaolinite", Cement and Concrete Research, vol. 33 (2003), pp. 405-416.

(10) Rahier, H.; Wullaert, B.; Van Mele, B.: "Influence of the degree of dehydroxilation of Kaolinite on the properties of aluminosilicate glasses", J. Thermal Anal. Calorim., vol. 62 (2000), pp. 417-427.

(11) Kakali, G. et al., "Thermal treatment of kaolin: the effect of mineralogy on the pozzolanic activity", Applied Clay Science, vol. 20 (2001), pp. 73-80.

(12) Ambroise, J.; Martin-Calle, S. y Pera, J.: "Pozzolanic Behavior of Thermally Activated Kaolin", Fly Ash, Silica Fume, Slag and Natural Pozzolans in Concrete (1992), pp. 731-747.

(13) Mejía de Gutiérrez, R.; Torres, J.; Guerrero, C.: "Análisis del Proceso Térmico de producción de una puzolana", Mater. Construcc., vol. 54, 74 (2004), pp. 65-72.

(14) Fagerlund, G.: "On the Capillarity of Concrete", Nordic Concrete Research, nº1 Paper n6 (1982), 20 pp.

(15) EMPA - SIA 162/1, Test No. 5 - Water Conductivity, Suiza, 1989.

(16) Khatib, J. y Clay, R.: "Absorption Characteristics of Metakaolin Concrete", Cement and Concrete Research, vol. 34 (2004), pp. 19-29.

(17) Frías, M. y Cabrera, J.: "Pore Size Distribution and Degree of Hydration of Metakaolin-Cement Pastes", Cement and Concrete Research, vol. 30 (2000), pp. 561-569.

(18) Batis, G.; Pantazopoulou, P.; Tsivilis, S. y Badogiannis, E.: "The effect of metakaolin on the corrosion behavior of cement mortars", Cement and Concrete Composites, vol. 27 (2005), pp. 125-130.

(19) Poon, C. S.; Kou, C. y Lam, L.: "Compressive Strength, chloride diffusivity an pore structure of high performance metakaolin and silica fume concrete", Construction and Building Materials, vol. 20, (2006), pp. 858-865.

(20) Mejía de Gutiérrez, R. M. de, Delvasto, S.; Gutiérrez, C. y Talero, R.: "Chloride Diffusion measured by a modified permeability test in normal and blended cements", Advanced in Cement Research, vol. 15, 3 (2003), pp. 113-118.

(21) Asbridge, H.; Chadbourn, G. A. y Page, C. L.: "Effects of Metakaolin and the Interfacial Zone on the Diffusion on chloride ions through Cement Mortars", Cement and Concrete Research, vol. 31 (2001), pp. 1567-1572. 